\title{
CARBON DIOXIDE CAPTURE FROM FLUE GAS USING DRY REGENERABLE SORBENTS
}

\author{
QUARTERLY TECHNICAL PROGRESS REPORT
}

Reporting Period: January 1, 2001 to March 31, 2001

\author{
by \\ David A. Green \\ Brian S. Turk \\ Raghubir P. Gupta \\ Alejandro Lopez-Ortiz \\ Douglas P. Harrison* \\ Ya Liang*
}

DOE Cooperative Agreement No.: DE-FC26-00NT40923

\author{
Submitted by: \\ Research Triangle Institute \\ Post Office Box 12194 \\ Research Triangle Park, NC 27709-2194 \\ *Louisiana State University \\ Department of Chemical Engineering \\ Baton Rouge, LA 70803
}

May 2001 


\section{DISCLAIMER}

This report was prepared as an account of work sponsored by an agency of the United States Government. Neither the United States Government nor any agency thereof, nor any of their employees, makes any warranty, express or implied, or assumes any legal liability or responsibility for the accuracy, completeness, or usefulness of any information, apparatus, product, or process disclosed, or represents that its use would not infringe privately owned rights. Reference herein to any specific commercial product, process, or service by trade name, trademark, manufacturer, or otherwise does not necessarily constitute or imply its endorsement, recommendation, or favoring by the United State Government or any agency thereof. The views and opinions of authors expressed therein do not necessarily state or reflect those of the United States Government or any agency thereof. 


\section{ABSTRACT}

Electrobalance studies of calcination and carbonation of sodium bicarbonate materials were conducted at Louisiana State University. Calcination in an inert atmosphere was rapid and complete at $120^{\circ} \mathrm{C}$. Carbonation was temperature dependent, and both the initial rate and the extent of reaction were found to decrease as temperature was increased between 60 and $80^{\circ} \mathrm{C}$. A fluidization test apparatus was constructed at RTI and two sodium bicarbonate materials were fluidized in dry nitrogen at $22^{\circ} \mathrm{C}$. The bed was completely fluidized at between 9 and $11 \mathrm{in}$. of water pressure drop. Kinetic rate expression derivations and thermodynamic calculations were conducted at RTI. Based on literature data, a simple reaction rate expression, which is zero order in carbon dioxide and water, was found to provide the best fit against reciprocal temperature. Simulations based on process thermodynamics suggested that approximately 26 percent of the carbon dioxide in flue gas could be recovered using waste heat available at $240^{\circ} \mathrm{C}$. 


\section{TABLE OF CONTENTS}

Page

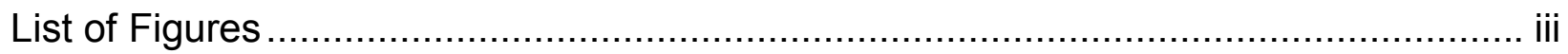

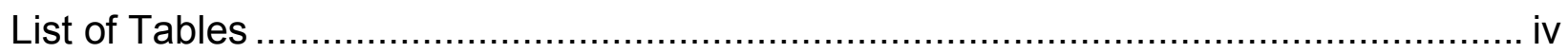

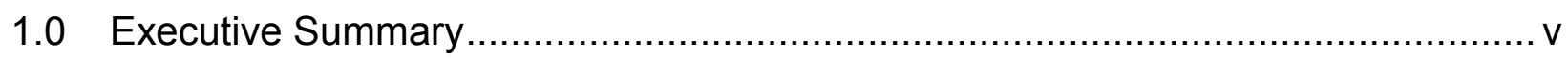

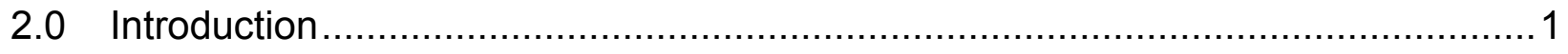

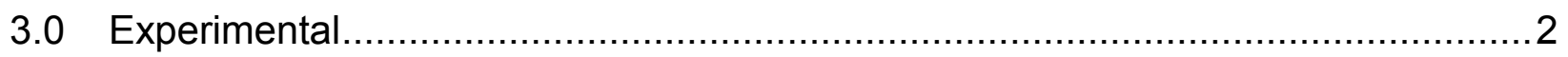

3.1 Electrobalance (Thermogravimetric Analysis) Testing .........................2

3.2 Fluidization Testing ..................................................................

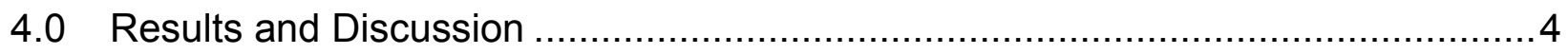

4.1 Electrobalance (TGA) Testing at LSU ............................................ 4

4.1.1 Typical Electrobalance Response Curve .................................. 4

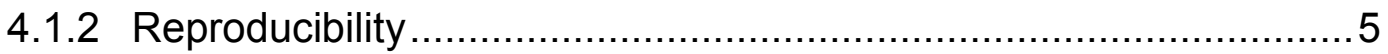

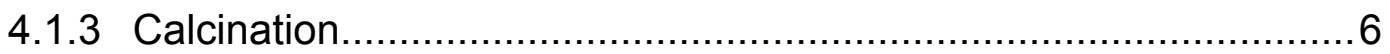

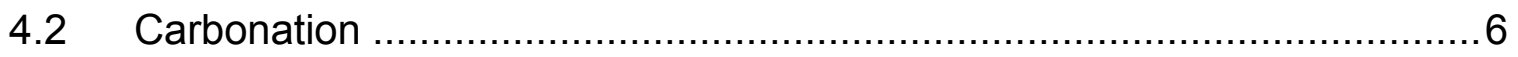

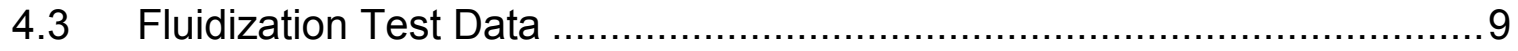

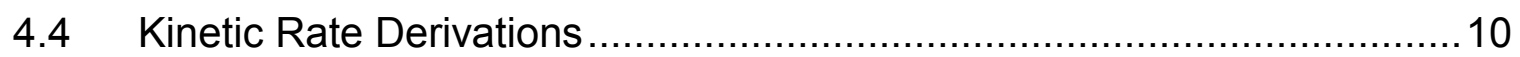

4.5 Process Simulation and Optimization ................................................ 11

4.6 Plans for Next Quarter ............................................................... 12

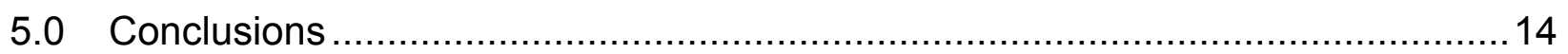

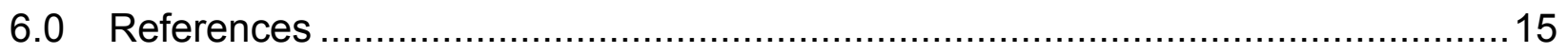




\section{LIST OF FIGURES}

Page

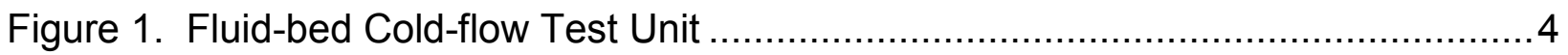

Figure 2. Typical Electrobalance Response During a Single Calcination-

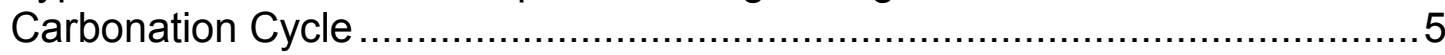

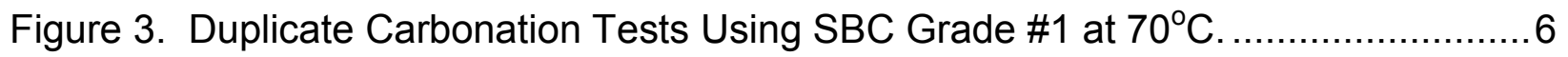

Figure 4. The Effect of Carbonation Temperature Using SBC Grade \#3 ..................... 7

Figure 5. Comparison of the Carbonation Results of Three Sorbents at $60^{\circ} \mathrm{C} \ldots \ldots \ldots \ldots . . . .8$

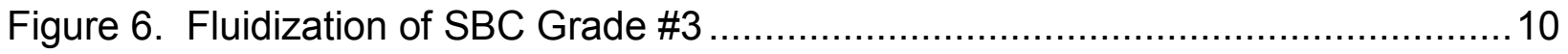

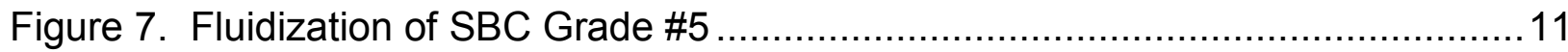

Figure 8. Conceptual Design of a $\mathrm{CO}_{2}$ Recovery Process Using Waste Heat from Flue Gas. 


\section{LIST OF TABLES}

$\underline{\text { Page }}$

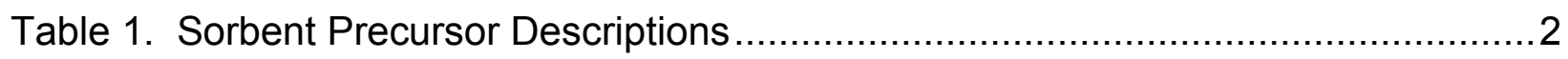

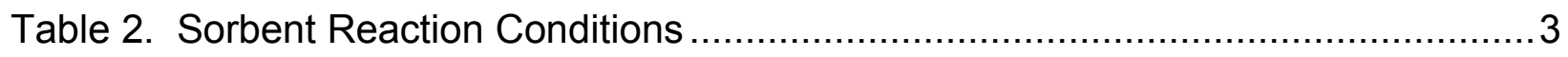

Table 3. Matrix of Completed Single-Cycle Tests .................................................... 3

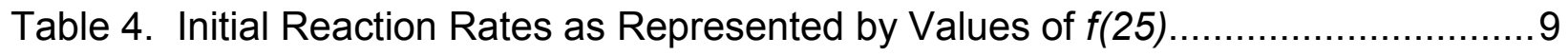

Table 5. Achievable Sorbent Capacity as Represented by Values of $f(200)$................. 9

Table 6. Reaction Data for Carbonation of Sodium Carbonate and Kinetic Rate Constants. 


\subsection{EXecutive SUMmaRY}

The objective of this project is to develop a simple, inexpensive process to separate $\mathrm{CO}_{2}$ as an essentially pure stream from a fossil fuel combustion system using a regenerable, sodiumbased sorbent. The sorbent being used in this project is sodium bicarbonate or "baking soda."

Sodium bicarbonate sorbents were calcined in an inert gas atmosphere in an electrobalance apparatus. Calcination to a final mass consistent with stoichiometric loss of carbon dioxide was rapid and essentially complete at $120^{\circ} \mathrm{C}$. Calcined materials were then exposed to a simulated, natural-gas-combustion flue gas of 8 percent carbon dioxide and 16 percent water vapor at 60,70 , and $80^{\circ} \mathrm{C}$. Both the initial rate of reaction and the final weight increased with decreasing temperature. The reaction rate approached zero after about $200 \mathrm{~min}$. The temperature dependence of the final weight is consistent with a reversible reaction model.

A fluidization test apparatus was constructed and used to determine pressure drop versus flow rate relationships for two of the sodium bicarbonate materials. Dry nitrogen was used to fluidize the materials at $22^{\circ} \mathrm{C}$. Pressure drop data were erratic until absorbed moisture had been removed from the materials. Under cold flow conditions, the bed could be completely fluidized at 9 to $11 \mathrm{in}$. of water pressure drop, corresponding to a superficial velocity of 5 to $10 \mathrm{ft} / \mathrm{min}$.

Kinetic rates of carbonation of sodium carbonate were derived from the literature and fitted to various reaction rate models. A reaction rate expression that was zero order in both carbon dioxide and water vapor provided the best fit against reciprocal temperature, and an equation representing this relationship is presented.

The thermodynamics of a cyclic calcination/carbonation process was investigated. The availability of waste heat in the flue gas for use in regeneration of the sorbent limits the extent of carbon dioxide recovery possible. Using heat available in flue gas at $240^{\circ} \mathrm{C}$, approximately 26 percent of the carbon dioxide present in the flue gas could be recovered with essentially no efficiency penalty to the power plant. 


\section{$2.0 \quad$ INTRODUCTION}

Increasing amounts of anthropogenic $\mathrm{CO}_{2}$ emitted into the atmosphere are believed to be a significant factor in global climate change. The Department of Energy's (DOE's) carbon sequestration roadmap makes large point sources of $\mathrm{CO}_{2}$ emissions (e.g., conventional, pulverized-coal, steam power plants; natural gas-fired combined cycle plants; and advanced power-generation systems) primary targets for carbon sequestration. Development of technologies to implement carbon sequestration at these large point sources is expected to have a rapid and significant impact on anthropogenic $\mathrm{CO}_{2}$ emissions. This technology development will provide an opportunity for the United States to take the lead in mitigating global greenhouse gas emissions.

Sodium bicarbonate $\left(\mathrm{NaHCO}_{3}\right)$ or trona $\left(\mathrm{Na}_{2} \mathrm{CO}_{3} \cdot \mathrm{NaHCO}_{3} \cdot 2 \mathrm{H}_{2} \mathrm{O}\right)$ may be used as the basis for a dry, regenerable sorbent technology to economically capture $\mathrm{CO}_{2}$ from dilute flue gas streams. Sodium bicarbonate, or "baking soda," is commonly used to capture $\mathrm{HCl}$ and $\mathrm{SO}_{2}$ from the flue gas but not to capture $\mathrm{CO}_{2}$. Note that $\mathrm{NaHCO}_{3}$ decomposes upon heating according to the reaction

$$
\text { [Decarbonation] } 2 \mathrm{NaHCO}_{3}(\mathrm{~s})=3 \mathrm{Na}_{2} \mathrm{CO}_{3}(\mathrm{~s})+\mathrm{CO}_{2}(\mathrm{~g})+\mathrm{H}_{2} \mathrm{O}(\mathrm{g})
$$

which releases $\mathrm{CO}_{2}$. Conversely, $\mathrm{NaHCO}_{3}$ is formed by

$$
\text { [Carbonation] } \quad \mathrm{Na}_{2} \mathrm{CO}_{3}(\mathrm{~s})+\mathrm{CO}_{2}(\mathrm{~g})+\mathrm{H}_{2} \mathrm{O}(\mathrm{g})=2 \mathrm{Na}_{2} \mathrm{CO}_{3}(\mathrm{~s})
$$

In this reaction, $\mathrm{CO}_{2}$ is absorbed from a flue gas stream by $\mathrm{NaHCO}_{3}$. Several patents (Krieg, et al., 1984; Sarapata et al., 1987; and Falotico, 1993) describe processes and process improvements to optimize Reaction (2).

The $\mathrm{NaHCO}_{3}$ can be subsequently regenerated by heating via Reaction (1). In effect, this chemistry enables $\mathrm{CO}_{2}$ to be separated from a low-pressure flue gas stream and converted into a pure $\mathrm{CO}_{2}$ stream for subsequent use or sequestration. reactions:

$\mathrm{HCl}$ and $\mathrm{SO}_{2}$ in the flue gas are also absorbed by $\mathrm{NaHCO}_{3}$ according to the following

$$
\begin{aligned}
& \mathrm{Na}_{2} \mathrm{CO}_{3}(\mathrm{~s})+2 \mathrm{HCl}(\mathrm{g})=2 \mathrm{NaCl}(\mathrm{s})+\mathrm{CO}_{2}(\mathrm{~g})+\mathrm{H}_{2} \mathrm{O}(\mathrm{g}), \\
& \mathrm{Na}_{2} \mathrm{CO}_{3}(\mathrm{~s})+\mathrm{SO}_{2}(\mathrm{~g})+{ }^{1} /{ }_{2} \mathrm{O}_{2}(\mathrm{~g})=\mathrm{Na}_{2} \mathrm{SO}_{4}(\mathrm{~s})+\mathrm{CO}_{2}(\mathrm{~g}) .
\end{aligned}
$$

In fact, Reactions (3) and (4) are used industrially for removing acidic compounds from incinerator and furnace stack gases (Maziuk, 1996). Commercial-grade $\mathrm{NaHCO}_{3}$ has also been used as an in-duct injection sorbent for removal of $\mathrm{SO}_{2}$ and $\mathrm{HCl}$ from hydrogen chloride flue gas streams generated in coal-fired power plants. Despite significantly better performance of $\mathrm{NaHCO}_{3}$ over limestone, its use for $\mathrm{SO}_{2}$ removal has gained limited commercial acceptance in the electric utility industry primarily because of its high cost when considered for one-time use (not regenerated). 
reactions:

Trona may also be used as a regenerable sorbent for $\mathrm{CO}_{2}$ according to the following

Trona is initially calcined according to

$$
2\left[\mathrm{Na}_{2} \mathrm{CO}_{3} \cdot \mathrm{NaHCO}_{3} \cdot 2 \mathrm{H}_{2} \mathrm{O}(\mathrm{s})\right] \quad 3 \mathrm{Na}_{2} \mathrm{CO}_{3}(\mathrm{~s})+\mathrm{CO}_{2}(\mathrm{~g})+5 \mathrm{H}_{2} \mathrm{O}(\mathrm{g})
$$

Subsequent carbonation and calcination reactions proceed according to

$$
3 \mathrm{Na}_{2} \mathrm{CO}_{3}(\mathrm{~s})+3 \mathrm{CO}_{2}(\mathrm{~g})+3 \mathrm{H}_{2} \mathrm{O}(\mathrm{g}) \quad 6 \mathrm{NaHCO}_{3}(\mathrm{~s})
$$

This report describes activities conducted between January 1, 2001 and March 31, 2001 by Research Triangle Institute (RTI) and subcontractors Louisiana State University (LSU) and Church and Dwight (C\&D). Activities conducted this quarter include electrobalance (thermogravimetric analysis [TGA]) studies at LSU, sorbent characterization at C\&D the assembly of a cold-flow fluidization test apparatus at RTI, fluidization testing at RTI, kinetic rate investigations based on literature data at RTI, and process optimization at RTI.

\subsection{EXPERIMENTAL}

\subsection{Electrobalance (Thermogravimetric Analysis) Testing}

Six sodium-based sorbents were forwarded to LSU from RTI-four grades of sodium bicarbonate $(\mathrm{SBC})$ from $\mathrm{C} \& \mathrm{D}$ and two grades of trona from Solvay (natural sodium sesquicarbonate, $\mathrm{Na}_{2} \mathrm{CO}_{3} \cdot \mathrm{NaHCO}_{3} \cdot 2 \mathrm{H}_{2} \mathrm{O}$ ). Selected properties of these materials, both asreceived and following calcination was reported in the initial RTI quarterly report (Green et al., 2001).

Table 1 describes the six sorbents and Table 2 summarizes the reaction conditions studied to date at LSU. All SBC samples from C\&D were effectively $100 \%$ pure; the primary difference was the particle size. The trona samples differed both in purity and particle size.

Table 1. Sorbent Precursor Descriptions

\begin{tabular}{l|l|l|l}
\multicolumn{2}{c|}{ Sorbent Precursor } & Manufacturer & \multicolumn{1}{c}{ Description } \\
\hline Grade \#1 & SBC & C\&D & USP Powdered \\
\hline Grade \#2 & SBC & C\&D & USP Fine Granular \\
\hline Grade \#3 & SBC & C\&D & USP Fine Powdered \\
\hline Grade \#5 & SBC & C\&D & USP Coarse Granular \\
\hline T-50 & Trona & Solvay & $93.5 \%$ Purity \\
\hline T-200 & Trona & Solvay & $97.5 \%$ Purity
\end{tabular}

Pressure during calcination and carbonation was limited to $1 \mathrm{~atm}$ for application to flue gases, while the calcination temperature and range of carbonation temperatures studied were based on prior thermodynamic analysis. The $\mathrm{CO}_{2}$ and $\mathrm{H}_{2} \mathrm{O}$ contents of the carbonation gas provide a reasonable approximation of actual contents resulting from the combustion of $\mathrm{CH}_{4}$ using 10 percent excess air. 
An electrobalance has been used during the initial experimental phase. All tests to date have used the same calcination conditions and the same carbonation gas composition. The sole reaction parameter studied to date has been carbonation temperature. An initial charge of approximately $75 \mathrm{mg}$ of sorbent precursor was heated from room temperature to $100^{\circ} \mathrm{C}$ at a rate of $5^{\circ} \mathrm{C} / \mathrm{min}$ and from $100^{\circ} \mathrm{C}$ to the final calcination temperature of $120^{\circ} \mathrm{C}$ at a rate of $1^{\circ} \mathrm{C} / \mathrm{min}$ under flowing He. After calcination was complete (as indicated by constant weight), the temperature was decreased at a rate of $1^{\circ} \mathrm{C} / \mathrm{min}$ - still under $\mathrm{He}$ - until the desired carbonation temperature $\left(60^{\circ} \mathrm{C}\right.$ to $\left.80^{\circ} \mathrm{C}\right)$ was reached. The gas composition was then changed to $8-\mathrm{mol} \%$ $\mathrm{CO}_{2}, 16-\mathrm{mol}^{2} \mathrm{H}_{2} \mathrm{O}$, balance $\mathrm{He}$ at $300 \mathrm{sccm}$, and carbonation was continued until the reaction rate approached zero.

Table 3 indicates the matrix of single-cycle experimental tests completed to date. An ' $x$ ' in the matrix indicates that a run has been completed using the indicated sorbent and carbonation temperature. Duplicate runs have been completed using SBC Grade $\# 1$ at $70^{\circ} \mathrm{C}$. As will be discussed, not all results are consistent at this time and selected runs will be repeated in the future.

\section{2 $\quad$ Fluidization Testing}

A cold flow fluidization test unit was designed and constructed at RTI in order to obtain data for designing a fluid-bed reactor. The test unit is constructed of 4-in. transparent polyvinyl chloride (PVC) pipe, fitted with a porous quartz frit to support the bed of sorbent material. A Brooks 5851-E mass flow controller, with a range of 0 to $50 \mathrm{slpm}$, is used to meter dry nitrogen to a plenum below the frit. Differential pressure is measured with a Capsuhelic model W32FNS129 gauge, connected to pressure taps below the frit and at the exit from the PVC pipe. The gas outlet tube is equipped with a fabric filter to control nuisance dust. The unit is shown in Figure 1.
Table 2. Sorbent Reaction Conditions

\begin{tabular}{|c|c|}
\hline \multicolumn{2}{|l|}{ Calcination } \\
\hline Temperature & $120^{\circ} \mathrm{C}$ \\
\hline Pressure & $1 \mathrm{~atm}$ \\
\hline Gas Composition & $100 \% \mathrm{He}$ \\
\hline \multicolumn{2}{|l|}{ Carbonation } \\
\hline Temperature & $\begin{array}{l}60^{\circ} \mathrm{C}, 70^{\circ} \mathrm{C} \text {, or } \\
80^{\circ} \mathrm{C}\end{array}$ \\
\hline Pressure & $1 \mathrm{~atm}$ \\
\hline Gas Composition & $\begin{array}{l}8 \mathrm{~mol} \% \mathrm{CO}_{2} \\
16 \mathrm{~mol} \% \mathrm{H}_{2} \mathrm{O} \\
76 \mathrm{~mol} \% \mathrm{He} \\
\end{array}$ \\
\hline Gas Flow Rate & $300 \mathrm{sccm}$ \\
\hline
\end{tabular}

Table 3. Matrix of Completed Single-Cycle Tests

\begin{tabular}{c|c|c|c|c|c|c} 
& \multicolumn{7}{|c}{ Sorbent } \\
\hline $\begin{array}{c}\text { Carbonation } \\
\text { Temperature, }{ }^{\circ} \mathrm{C}\end{array}$ & \#1 & \#2 & \#3 & \#5 & T-50 & T-200 \\
\hline 60 & $\mathrm{X}$ & & $\mathrm{X}$ & & $\mathrm{x}$ & \\
\hline 70 & $\mathrm{x}, \mathrm{x}$ & $\mathrm{x}$ & $\mathrm{x}$ & $\mathrm{x}$ & $\mathrm{x}$ & $\mathrm{x}$ \\
\hline 80 & $\mathrm{x}$ & & $\mathrm{x}$ & & $\mathrm{x}$ &
\end{tabular}




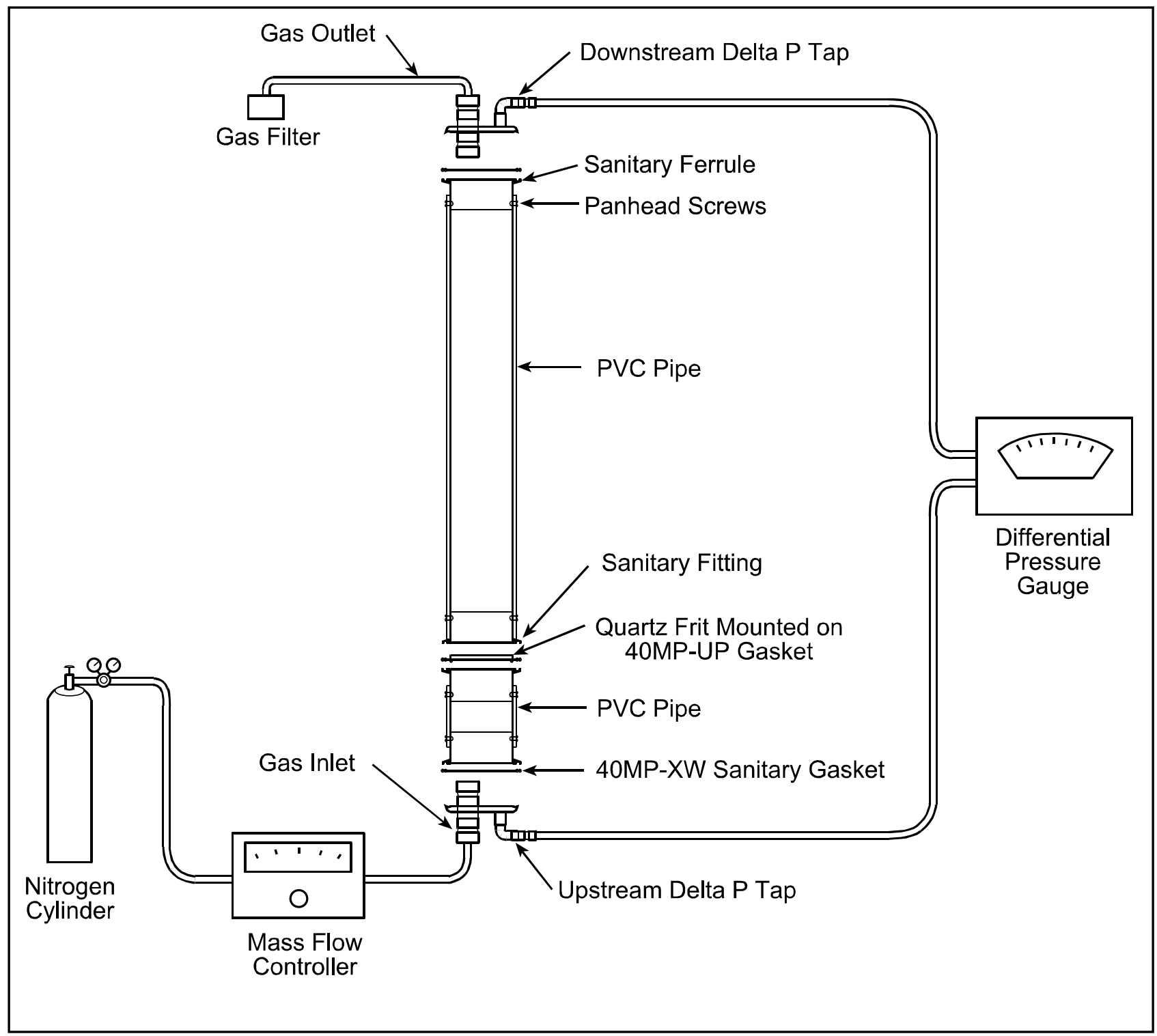

Figure 1. Fluid-bed Cold-flow Test Unit

RTI conducted fluidization tests to determine pressure drops as a function of gas velocity on two sodium bicarbonate materials.

\subsection{Results AND Discussion}

\subsection{Electrobalance (TGA) Testing at LSU}

\subsubsection{Typical Electrobalance Response Curve}

A typical, single-cycle, electrobalance response curve is shown in Figure 2, where dimensionless sample weight and temperature are shown as a function of time. SBC Grade \#3 sorbent was used in this test at a carbonation temperature of $60^{\circ} \mathrm{C}$, following calcination of the sorbent. Decomposition of $\mathrm{NaHCO}_{3}$ to $\mathrm{Na}_{2} \mathrm{CO}_{3}$ began at about $100^{\circ} \mathrm{C}$ and was complete soon 
after the final calcination temperature of $120^{\circ} \mathrm{C}$ was reached. The final dimensionless weight, $m_{f}$, is quite near the theoretical value of 0.631 that is indicated by the horizontal dashed line.

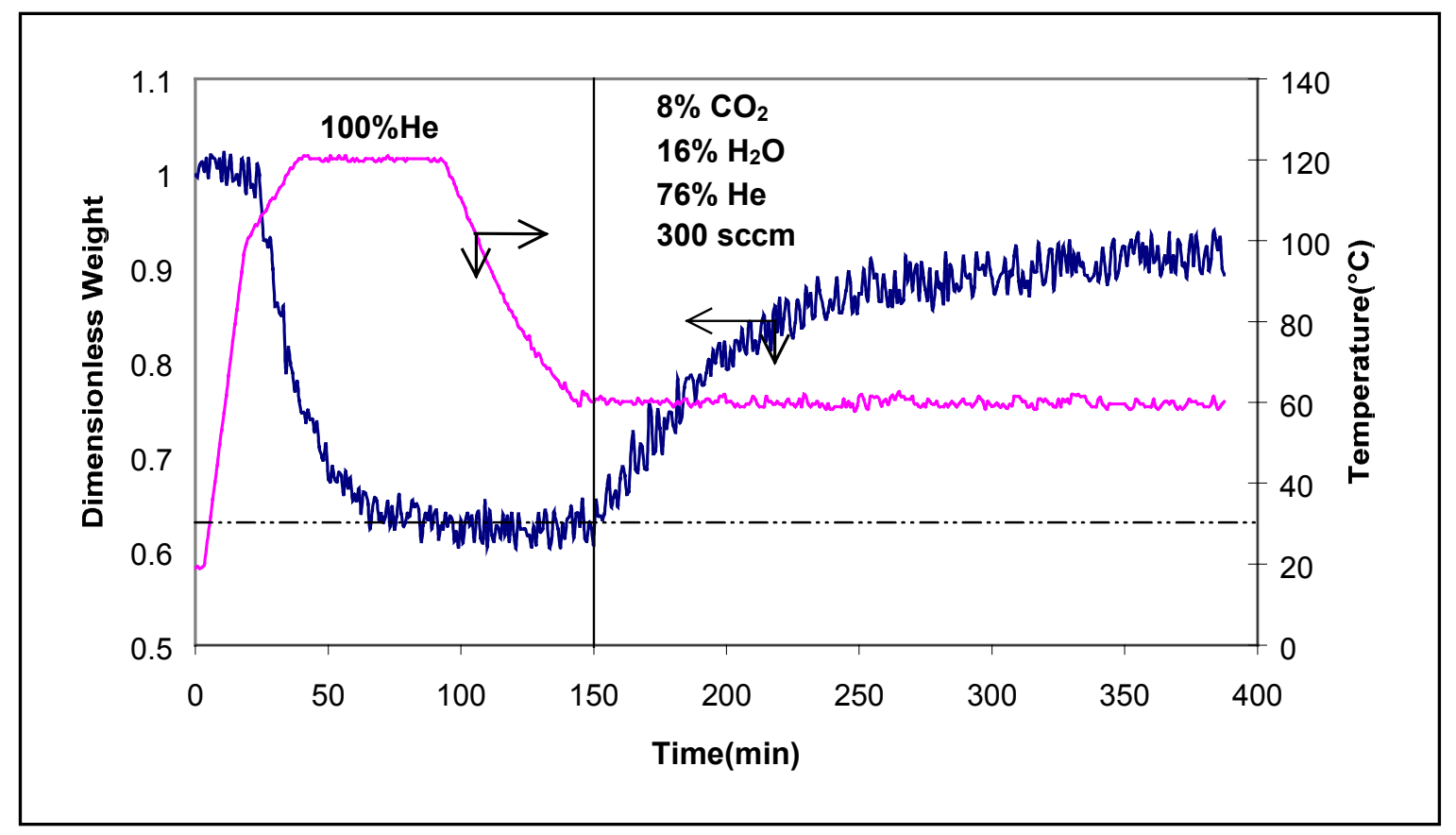

Figure 2. Typical Electrobalance Response During a Single Calcination-Carbonation Cycle

The temperature was then decreased to the $60^{\circ} \mathrm{C}$ carbonation temperature. $\mathrm{CO}_{2}$ and $\mathrm{H}_{2} \mathrm{O}$ were added after $150 \mathrm{~min}$ to produce the desired carbonation gas composition at a total flow rate of $300 \mathrm{sccm}$. The dimensionless weight increase corresponded to removal of $\mathrm{CO}_{2}$ from the gas phase via the conversion of $\mathrm{Na}_{2} \mathrm{CO}_{3}$ to $2 \mathrm{NaHCO}_{3}$. The global reaction rate, which is related to the slope of the dimensionless weight-time curve, begins at a high value, decreases with time, and approaches zero after about $300 \mathrm{~min}$. Complete carbonation would produce a final dimensionless weight of 1.0 and fractional carbonation as a function of time, $f(t)$, can be calculated from

$$
f(t)=\frac{m(t)-0.631}{1.0-0.631}=\frac{m(t)-0.631}{0.369}
$$

$m(t)$ is the dimensionless weight at time $t$ after the beginning of carbonation. In this example test $f(200)$ (measured between 150 and $350 \mathrm{~min}$ ), is approximately 0.67 . The results shown in Figure 2 are typical of all tests completed to date.

\subsubsection{Reproducibility}

Figure 3 shows the dimensionless weight as a function of time during the carbonation phase of the two tests at $70^{\circ} \mathrm{C}$ using $\mathrm{SBC}$ sorbent Grade $\# 1$. Electrobalance noise shown in Figure 2 has been removed by smoothing the data so that the individual test results may be clearly distinguished. There is considerable difference in early results from the two tests, but little difference after about 130 minutes. 


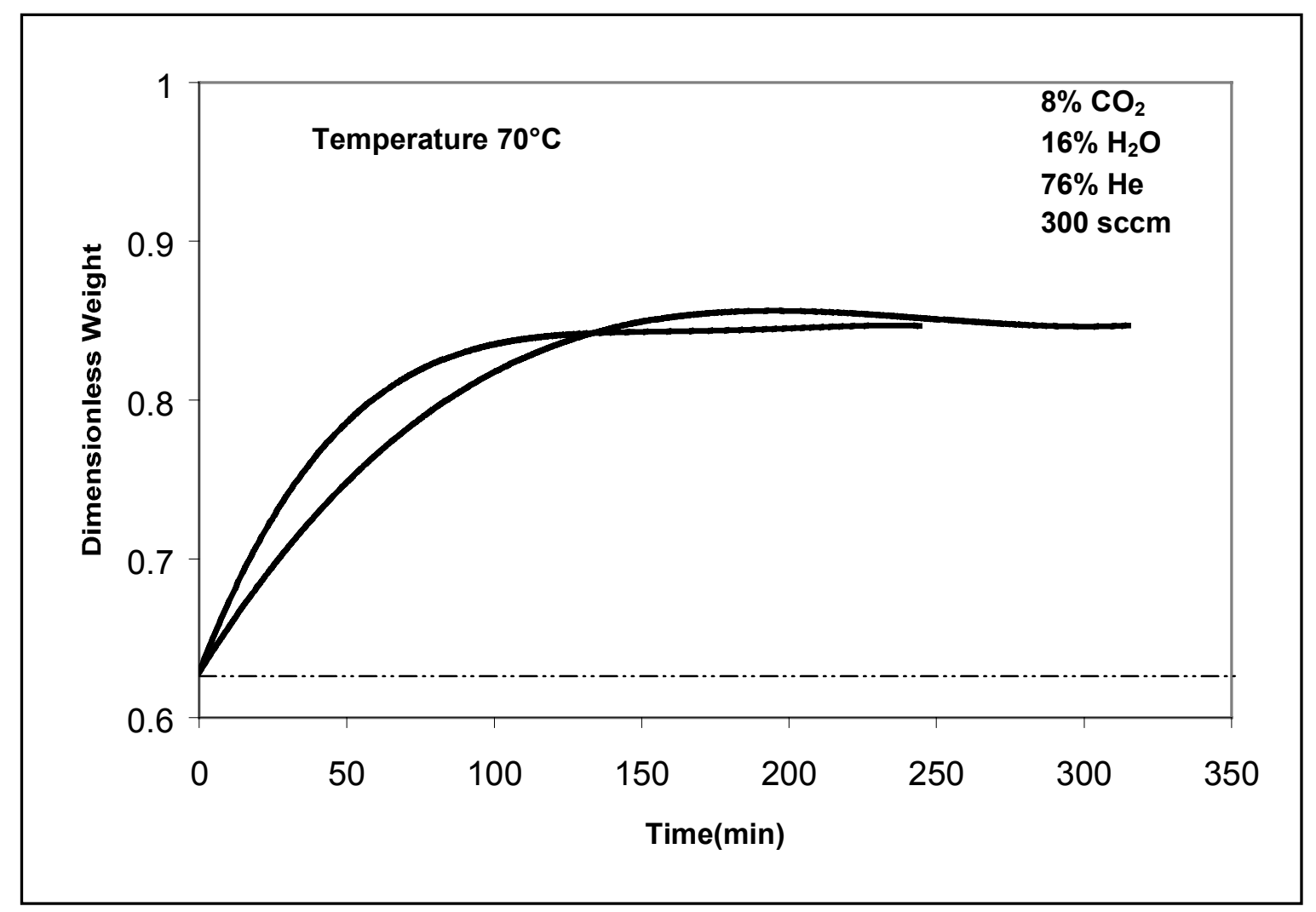

Figure 3. Duplicate Carbonation Tests Using SBC Grade \#1 at $70^{\circ} \mathrm{C}$.

Note that one of the tests shows a maximum dimensionless weight after about $200 \mathrm{~min}$. While there is no readily apparent reason why this maximum should exist, possible causes are currently being investigated. Possibilities include an anomaly associated with the data smoothing routine and/or temperature fluctuations during the experiment.

\subsubsection{Calcination}

As indicated in the previous section, the theoretical value of the final dimensionless weight corresponding to complete calcination of $\mathrm{NaHCO}_{3}$ is 0.631 . Final experimental values, which ranged from 0.622 to 0.637 , were all consistent with complete calcination.

The theoretical dimensionless weights corresponding to complete calcination of the trona samples are different because of the different initial composition and presence of impurities. The following values for final dimensionless weight were calculated based on the assumption that the impurities are nonvolatile. For T-200 containing $2.5 \%$ impurities, $m_{f}=0.711$, and for T-50 with $6.5 \%$ impurities, $m_{f}=0.723$. Experimental values for the three tests using T-50 were consistent with the theoretical value and ranged from 0.717 to 0.727 . However, in the single test using T-200, the experimental value of $m_{f}=0.760$ was significantly above the theoretical value.

\subsection{Carbonation}

Figure 4 compares the smoothed results for the three tests using SBC Grade \#3 at temperatures of $60^{\circ} \mathrm{C}, 70^{\circ} \mathrm{C}$, and $80^{\circ} \mathrm{C}$. Only the carbonation portion of the cycle is shown, and 
$t=0$ corresponds to the introduction of reactive $\mathrm{CO}_{2}$ and $\mathrm{H}_{2} \mathrm{O}$. Both the initial rate of reaction, as measured by the initial slope of the dimensionless weight-time curve, and the final dimensionless weight increased with decreasing temperature. In addition, the reaction rate approached zero after about $200 \mathrm{~min}$ of carbonation at both $60^{\circ} \mathrm{C}$ and $70^{\circ} \mathrm{C}$, while the reaction rate was small, but finite, after $200 \mathrm{~min}$ at $80^{\circ} \mathrm{C}$. An additional run at lower temperature, say $50^{\circ} \mathrm{C}$, is impossible with this feed gas composition because the dew point of the gas is above $50^{\circ} \mathrm{C}$.

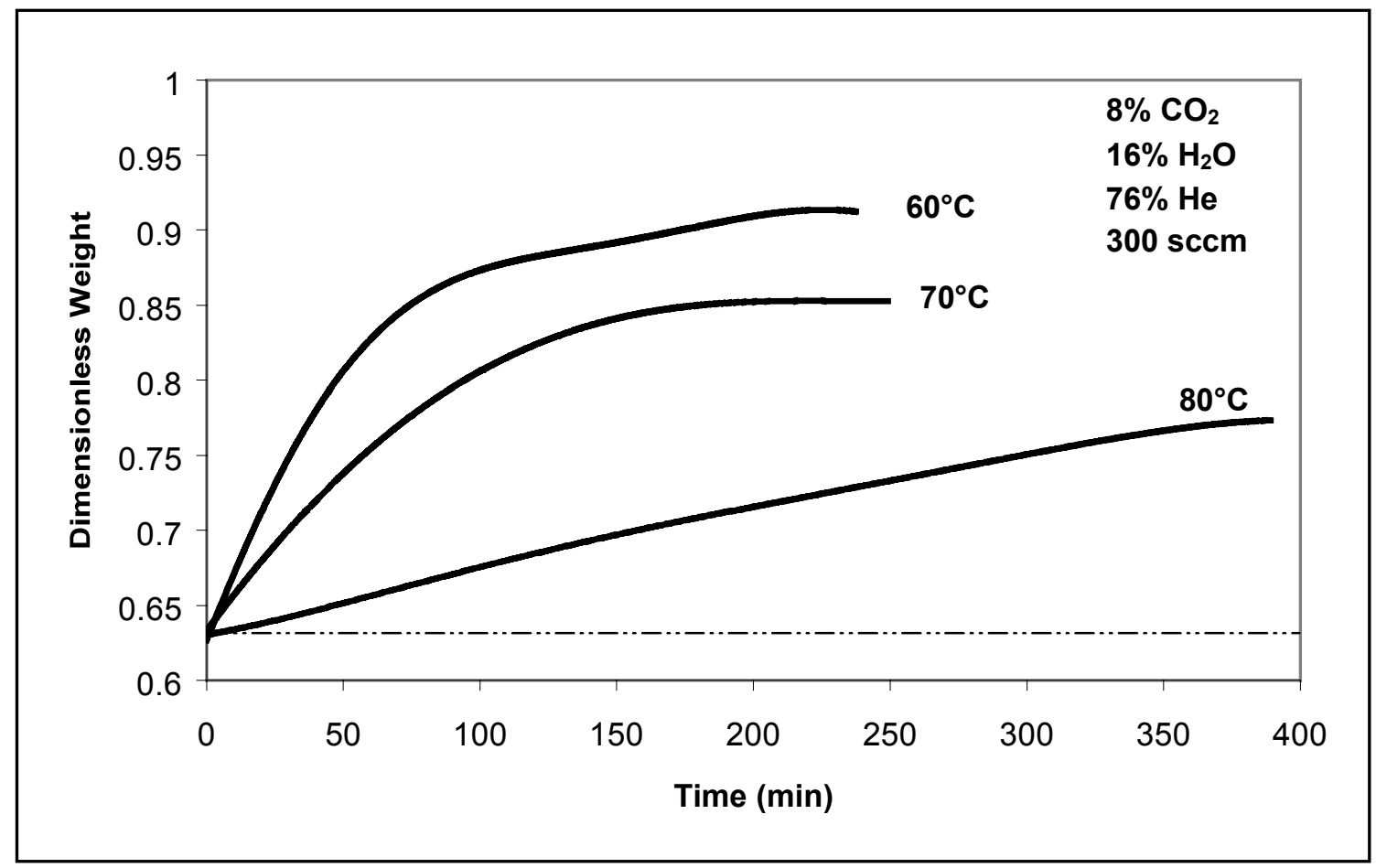

Figure 4. The Effect of Carbonation Temperature Using SBC Grade \#3

The decreasing rate with increasing temperature is attributed to reaction reversibility. The carbonation reaction is exothermic and equilibrium fractional $\mathrm{CO}_{2}$ removal decreases with increasing temperature. It is reasonable to speculate that the reaction rate is proportional to the difference between the $\mathrm{CO}_{2}$ concentration in the bulk gas and the equilibrium $\mathrm{CO}_{2}$ concentration at that temperature. The "HSC Chemistry" program was used to calculate the equilibrium mole fraction of $\mathrm{CO}_{2}$ as a function of temperature, and the difference between bulk and equilibrium concentrations was calculated from the following equation:

$$
C_{A o}-C_{A e}=\frac{\left(y_{A o}-y_{A e}\right) P}{R T}
$$

$C_{A o}$ and $C_{A e}$ are the bulk and equilibrium concentrations of $\mathrm{CO}_{2}, y_{A o}$ and $y_{A e}$ are the bulk and equilibrium mole fractions of $\mathrm{CO}_{2}, P$ is the pressure, $R$ is the gas constant, and $T$ is the absolute temperature. The results are:

$$
\begin{array}{ll}
\mathrm{T}=60^{\circ} \mathrm{C} & \mathrm{C}_{\mathrm{Ao}}-\mathrm{C}_{\mathrm{Ae}}=0.0028 \mathrm{~mol} / \mathrm{L} \\
\mathrm{T}=70^{\circ} \mathrm{C} & \mathrm{C}_{\mathrm{Ao}}-\mathrm{C}_{\mathrm{Ae}}=0.0025 \mathrm{~mol} / \mathrm{L}
\end{array}
$$




$$
\mathrm{T}=80^{\circ} \mathrm{C} \quad \mathrm{C}_{\mathrm{Ao}}-\mathrm{C}_{\mathrm{Ae}}=0.0016 \mathrm{~mol} / \mathrm{L} .
$$

Thus, the $\mathrm{CO}_{2}$ reaction-driving force is reduced by more than 40 percent at $80^{\circ} \mathrm{C}$ compared to $60^{\circ} \mathrm{C}$.

Figure 5 compares the dimensionless weight-versus-time response during the carbonation cycle for three samples - SBC Grades \#1 and \#3 and trona T-50 - for a reaction temperature of $60^{\circ} \mathrm{C}$. The initial dimensionless weights are again very close to the theoretical values of 0.631 for SBC and 0.723 for trona T-50. The initial reaction rates, as measured by the slopes of the curves between $t=0$ and $t=25 \mathrm{~min}$, are approximately equal. Similarly, the final dimensionless weights for the two SBC samples are reasonably close. Note that the larger final value of dimensionless weight for trona T-50 does not necessarily correspond to increased fractional carbonation since the final dimensionless weight corresponding to complete carbonation of that sample would be about 1.12 .

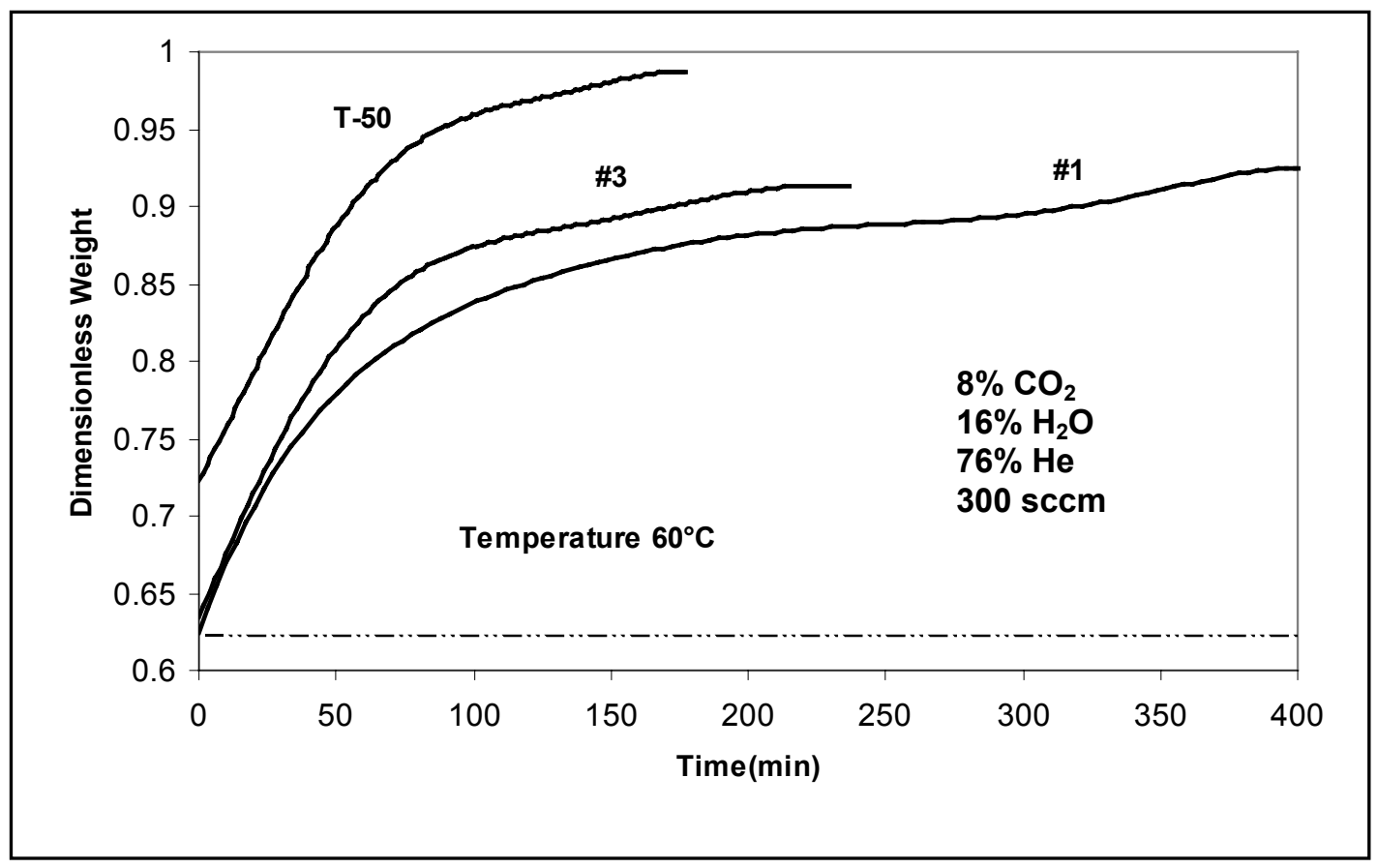

Figure 5. Comparison of the Carbonation Results of Three Sorbents at $60^{\circ} \mathrm{C}$

The previous figures indicate that the dimensionless weight-time curves are approximately linear during the early stages of the reaction and that carbonation is essentially complete after $200 \mathrm{~min}$ at both $60^{\circ} \mathrm{C}$ and $70^{\circ} \mathrm{C}$. As a result, fractional carbonation after $25 \mathrm{~min}$ was arbitrarily selected to represent the initial reaction rate and fractional carbonation after 200 min to represent the realistically achievable sorbent capacity. Fractional conversions $f(25)$ and $f(200)$ were calculated according to Equation 7 for the SBC sorbents and according to Equations 9 and 10 for the trona sorbents.

$$
f(t)=\frac{m(t)-0.723}{1.12-0.723}=\frac{m(t)-0.723}{0.397} \quad \text { Trona } \mathrm{T}-50
$$




$$
f(t)=\frac{m(t)-0.711}{1.12-0.711}=\frac{m(t)-0.711}{0.409} \quad \text { Trona } \mathrm{T}-200
$$

$f(25)$ and $f(200)$ results are summarized in matrix form in Tables 4 and 5, respectively.

Table 4. Initial Reaction Rates as Represented by Values of $f(25)$

\begin{tabular}{c|c|c|c|c|c|c} 
& \multicolumn{6}{|c}{ Sorbent } \\
\hline $\begin{array}{c}\text { Carbonation } \\
\text { Temperature, }{ }^{\circ} \mathrm{C}\end{array}$ & SBC \#1 & SBC \#2 & SBC \#3 & SBC \#5 & T-50 & T-200 \\
\hline 60 & 0.25 & & 0.24 & & 0.22 & \\
\hline 70 & $0.16,0.08$ & 0.14 & 0.16 & 0.15 & 0.13 & 0.24 \\
\hline 80 & 0.02 & & 0.02 & & 0.19 &
\end{tabular}

Table 5. Achievable Sorbent Capacity as Represented by Values of $f(200)$

\begin{tabular}{c|c|c|c|c|c|c} 
& \multicolumn{7}{|c}{ Sorbent } \\
\hline $\begin{array}{c}\text { Carbonation } \\
\text { Temperature, }{ }^{\circ} \mathrm{C}\end{array}$ & SBC \#1 & SBC \#2 & SBC \#3 & SBC \#5 & T-50 & T-200 \\
\hline 60 & .067 & & 0.67 & & 0.67 & \\
\hline 70 & $0.59,0.62$ & 0.59 & 0.60 & 0.61 & 0.53 & 0.59 \\
\hline 80 & 0.29 & & 0.23 & & 0.49 &
\end{tabular}

Table 4 shows, in general, that the initial reaction rate decreases with increasing temperature. This is certainly true for SBC Grades $1 \#$ and \#3, but not necessarily true for trona T-50. Achievable capacity, $f(200)$, also appears to decrease with increasing temperature. All sorbents tested at all three temperatures show this effect, but the decrease observed with trona $\mathrm{T}$ 50 is smaller than with either of the SBC sorbents.

There appears to be relatively little difference in either the initial reaction rate or the achievable capacity among the different sorbents. At $60^{\circ} \mathrm{C}$, both the initial rate and achievable capacity are effectively equal for SBC Grade \#1, SBC Grade \#3, and trona T-50. Similarly, five of the seven tests at $70^{\circ} \mathrm{C}$ produced similar initial rates, and the achievable conversion was reasonably close for all seven tests. Both $\mathrm{NaHCO}_{3}$ sorbents tested at $80^{\circ} \mathrm{C}$ gave similar initial rates and achievable conversion, but results using trona $\mathrm{T}-50$ were quite different.

Identification of the 'outlying' results from Tables 4 and 5 provides guidance for selecting tests that should be repeated. The candidates for repeat tests are SBC Grade \#1 at $70^{\circ} \mathrm{C}$, trona $\mathrm{T}-200$ at $70^{\circ} \mathrm{C}$, and trona $\mathrm{T}-50$ at $80^{\circ} \mathrm{C}$.

\subsection{Fluidization Test Data}

Fluidization tests were conducted on SBC Grade \#3 and SBC Grade \#5 in the cold-flow test apparatus to obtain pressure drops and minimum fluidization velocities for design of the fluidized-bed reactor system. Both materials were tested at $22^{\circ} \mathrm{C}$ with sorbent masses of $2.5 \mathrm{~kg}$. Initial attempts to test these materials led to erratic pressure drop data, which probably resulted from small amounts of moisture in the sorbent. Because the fluidizing gas used was dry nitrogen from a compressed gas cylinder, the pressure drop data stabilized after the fluidizing gas passed through the bed for a few hours. The data presented in Figures 6 and 7 represent test data 
obtained on fresh SBC Grade \#3 and SBC Grade \#5 sorbents after they had been dried in the fluidization apparatus.

The data suggest that the bed can be completely fluidized at a pressure drop of 9 to $11 \mathrm{in}$. of water, corresponding to a superficial velocity of 5 to $10 \mathrm{ft} / \mathrm{min}$. The mass of the bed, $2.5 \mathrm{~kg}$ $(5.5 \mathrm{lb})$ divided by the cross-sectional area of the test apparatus, $81.3 \mathrm{~cm}^{2}\left(12.6 \mathrm{in}^{2}\right)$, corresponds to a pressure of about 12 in. of water. Additional tests on other sorbents, as well as calcined sorbents are planned for the next quarter.

\subsection{Kinetic Rate Derivations}

RTI derived kinetic rate constants for use in reactor design from the examples given by Sarapata, et al. (1987). The data, which included eight usable measurements, were tested against five different reaction rate expressions. Equations 11 through 15 represent the models tested:

$$
\begin{aligned}
-\ln (1-\mathrm{X}) & =\mathrm{k}_{1} \mathrm{t} \\
-\ln (1-\mathrm{X}) & =\mathrm{k}_{2} \mathrm{PCO}_{2} \mathrm{t} \\
-\ln (1-\mathrm{X}) & =\mathrm{k}_{3} \mathrm{P}_{\mathrm{CO}_{2}} \mathrm{P}_{\mathrm{H}_{2} \mathrm{O}} \mathrm{t} \\
-\ln (1-\mathrm{X}) & =\mathrm{k}_{4}\left(\mathrm{P}_{\mathrm{CO}_{2}} \mathrm{P}_{\left.\mathrm{H}_{2} \mathrm{O}-\mathrm{K}_{\mathrm{eq}}\right) \mathrm{t}}\right. \\
-\ln (1-\mathrm{X}) & =\mathrm{k}_{5} \mathrm{P}_{\mathrm{H}_{2} \mathrm{O}} \mathrm{t}
\end{aligned}
$$

where,

$\mathrm{X}=$ the extent of Reaction (2)

$\mathrm{P}_{\mathrm{CO} 2}=$ the partial pressure of $\mathrm{CO}_{2}$, atm

$\mathrm{P}_{\mathrm{H} 20}=$ the partial pressure of $\mathrm{H}_{2} \mathrm{O}$, atm

$\mathrm{t}=$ reaction time, $\min$

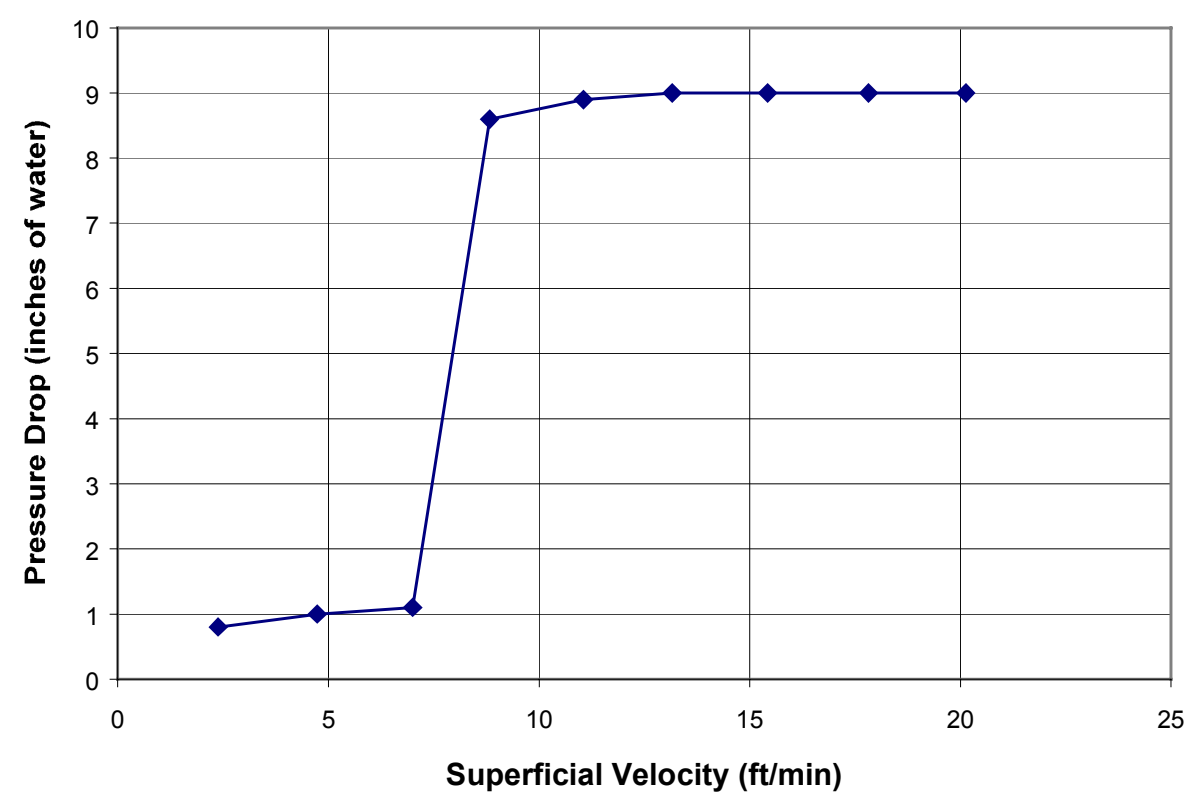

Figure 6. Fluidization of SBC Grade \#3 


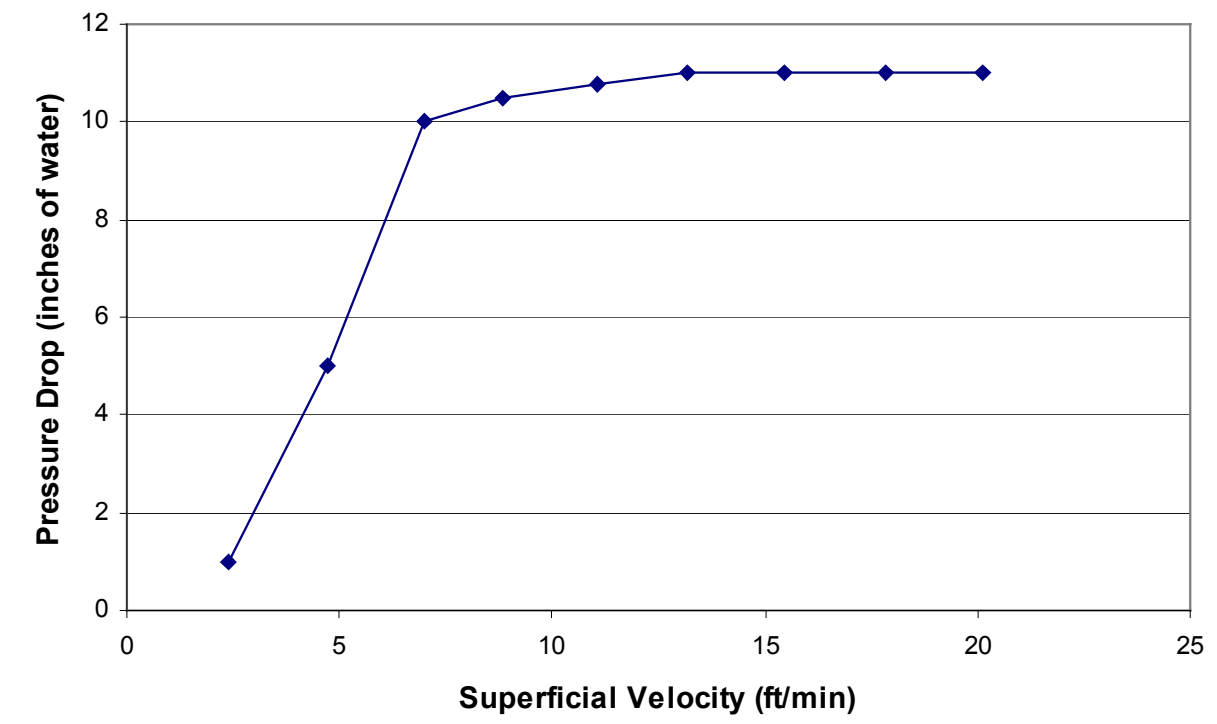

Figure 7. Fluidization of SBC Grade \#5

$\mathrm{K}_{\mathrm{eq}}=$ the temperature-specific equilibrium constant for Reaction (1), calculated as,

$\ln \left(\mathrm{K}_{\mathrm{eq}}\right)=40.23-(15445 / \mathrm{T})$

where,

$\mathrm{T}=$ the temperature, $\mathrm{K}$

and $\mathrm{k}_{1}$ through $\mathrm{k}_{5}$ are the relevant kinetic constants.

Sarapata's data and the corresponding kinetic constants are given in Table 6.

When the derived rate constants were tested for linearity against the inverse absolute reaction temperature, the best fit was obtained with the constants derived from Reaction (11). Based on Sarapata's data,

$$
\mathrm{k}_{1}=1.572 \times 10^{3} \mathrm{e}^{(-3550 / \mathrm{T})}
$$

This value of rate constant will be compared with the TGA results of LSU and benchscale testing to be conducted at RTI.

\subsection{Process Simulation and Optimization}

The most significant limitation on the use of the sorbents investigated is the availability of process energy to regenerate the sorbent and release a concentrated carbon dioxide stream. The exothermic reaction of carbon dioxide with sodium carbonate occurs rapidly at temperatures below $70^{\circ} \mathrm{C}$. Energy available at this temperature has a low value. Regeneration of the sodium bicarbonate takes place readily at temperatures greater than $110^{\circ} \mathrm{C}$. Waste heat in flue gas is generally used to preheat combustion air and boiler feed water. Following recovery of heat for these purposes, flue gas is often available for discharge at 175 to $250^{\circ} \mathrm{C}$. Following sorbent regeneration, the flue gas would still require a temperature sufficient to rise through the 
discharge stack, typically 70 to $80^{\circ} \mathrm{C}$. An iterative calculation was done to determine the extent of carbon dioxide removal from coal fired power plant flue gas. Using the heat available in flue gas at $240^{\circ} \mathrm{C}$ to regenerate sodium carbonate, approximately 26 percent of the carbon dioxide could be recovered without using any additional external heat for regeneration. This indicates that under this process configuration, removal of $26 \% \mathrm{CO}_{2}$ from flue gas should be relatively inexpensive.

A conceptual design of a carbon dioxide recovery process based on coal-fired flue gas is shown in Figure 8.

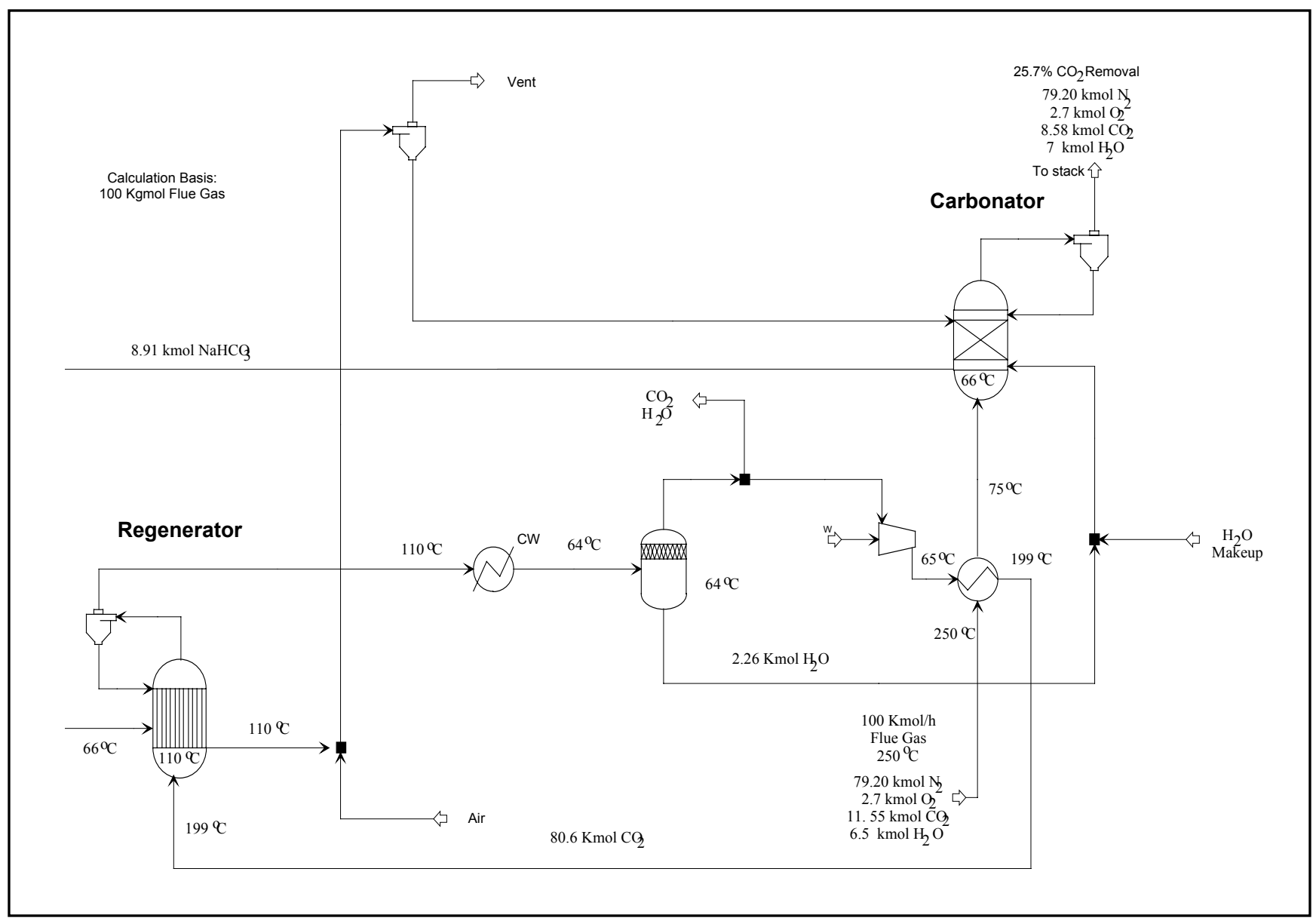

Figure 8. Conceptual Design of a $\mathrm{CO}_{2}$ Recovery Process Using Waste Heat from Flue Gas

\subsection{Plans for Next Quarter}

In the next quarter, RTI will design and construct a bench-scale fluidized bed reactor system. In addition, process simulations that have been conducted will be refined to further specify intermediate material and energy flows. Additional cold-flow fluidization tests will be conducted on dried SBC and trona materials and on selected calcined materials. Reaction rates determined using the Sarapata (1987) patent will be compared with the rate constants obtained from TGA studies at LSU. 


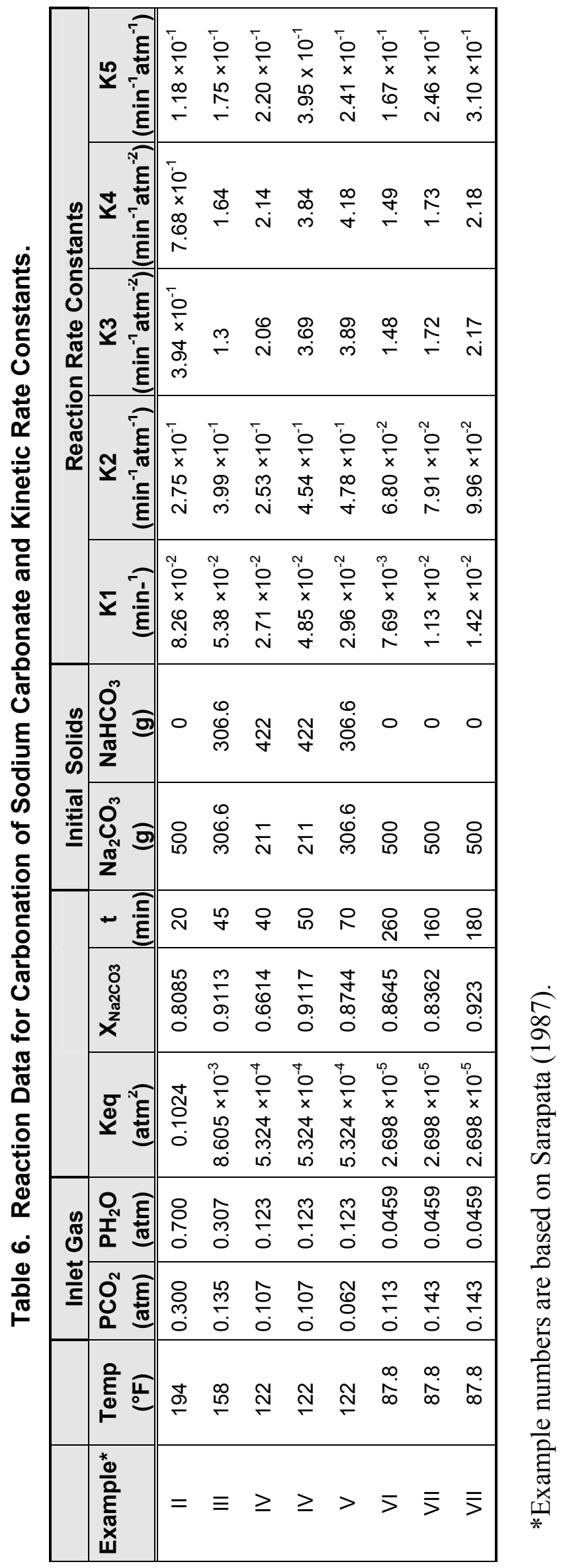


LSU will continue electrobalance testing of carbonation and regeneration reactions, and repeat tests where precision appears questionable. C\&D will undertake additional materials characterization determination, particularly focusing on additional surface areas measurements, and will also advise RTI on various engineering issues involved with injection of $\mathrm{H}_{2} \mathrm{O}$ during carbonation and regeneration of sorbent to monohydrate phase.

\subsection{CONCLUSIONS}

1. Electrobalance studies indicated that sodium bicarbonate materials could be rapidly calcined in an inert atmosphere at $120^{\circ} \mathrm{C}$.

2. The reaction of sodium carbonate and carbon dioxide, in gas representative of flue gas from natural gas combustion, was temperature dependent, both with regard to initial rate and extent of reaction, in the range of 60 to $80^{\circ} \mathrm{C}$.

3. Two sodium bicarbonate sorbent materials were fluidized in dry nitrogen in RTI's fluidization test apparatus at superficial velocities of 5 to $10 \mathrm{ft} / \mathrm{min}$. The fluidization characteristics of these sorbents matched with standard catalysts used in petroleum refineries.

4. Based on literature data, the rate of reaction of sodium carbonate to sodium bicarbonate can be represented by

$-\ln (1-\mathrm{X})=\mathrm{k}_{1} \mathrm{t}$, where

$\mathrm{k}_{1}=1.572 \times 10^{3} \mathrm{e}^{(-3550 / \mathrm{T})}$

5. Using waste heat available in natural gas combustion gas, process simulations indicated that approximately 26 percent of the carbon dioxide produced can be captured in a cyclic calcination/carbonation scheme. 


\subsection{REFERENCES}

Falotico, A.J., "Dry Carbonation of Trona.” PCT Application No.: PCT/US92/06321 (WO 93/11010), assigned to C \& D. June 10, 1993.

Green, D.A., Turk, B.S., Gupta, R., and Lopez Ortiz, A., Carbon Dioxide Capture From Flue Gas Using Dry Regenerable Sorbents, Quarterly Technical Progress Report, Research Triangle Institute, January 2001.

Krieg, J.P., et al., "Dry Carbonation Process.” U. S. Patent No.: 4,459,272, assigned to C \& D. July 10, 1984.

Maziuk, J. "Comparison of Dry Sorbent Injection of Sodium Bicarbonate, Lime and Carbon and Their Control of Dioxins/Furans, Mercury, Chlorides and Sulfur Dioxides." Presented in the Annual Meeting of Air and Waste Management Association. 1996.

Sarapata, J.S., et al., "Method for the Preparation of a Bicarbonate Sorbent in Flue Gas Desulfurization.” U.S. Patent No.: 4,664,893, assigned to C \& D. May 12, 1987. 